UDC 101.1:316+1(091)

DOI: https://doi.org/10.26661/hst-2019-2-79-01

\title{
ON THE WAY TO «NEW ENLIGHTENMENT» AS AN ALTERNATIVE TO CONSUMER SOCIETY
}

\author{
(C) VODOP'YANOV, PAVEL \\ Belarusian State Technical University (Republic of Belarus, Minsk) \\ E-mail: pva1940@bk.ru, ORCID iD: http://orcid.org/ 0000-0002-7881-4114 \\ Belarus \\ Belarusian State Technical University 13a, Sverdlova str., Minsk, 220006,Republic of

\section{(C) SIDORENKO, IRINA} \\ Belarusian State University (Republic of Belarus, Minsk) \\ E-mail: iri_na2000@rambler.ru, ORCID iD: http://orcid.org/0000-0001-7792-0102 \\ Belarusian State University 9, Kal'variyskaya str., Minsk, 220050,Republic of Belarus
}

\begin{abstract}
The purpose of this study isto identify the main risks and dangers of consumer society, turned the mind into an utilitarian tool for violence against nature, and on this basis to reveal the feasibility of the transition to «new» Enlightenment, involving the implementation of the strategy adequate development and formation of noospheric worldview.Methodology of research arethe complex methodology, namely: historical and logical methods, the method of comparative analysis, the method of historical and philosophical reconstruction, systemic method. As a methodological base the authors of this article have made the concept of negative dialectics and social destruction of T. Adorno and M. Horkheimer; the concept of consumer society of J.Baudrillard; and the author's development of the sustainable development strategy and strategy of sufficient development (P.A. Vodopyanov, V.S. Krisachenko), the author's project of philosophy of violence (I.N. Sidorenko).The scientific novelty of the researchconsists in a substantiation of the concept of sufficient development on the basis of the "new» Enlightenment and formation of noospheric worldview, as well as identifying the methodological potential of the concept of negative dialectics and social destruction to understand the causes of global crises of our time, in particular, environmental.As the main conclusions, the authors develop, at the first, the idea that overcoming environmental difficulties in the relationship between man and nature purely technical means is just one of the necessary conditions for achieving the sustainable future; at the second, reveal the essence of the «new» Enlightenment as the harmonization of development and protection, which finds its implementation in the concept of sufficient development and involves the connection of action for the progressive development and security into a single system; at the third, the idea of special importance in overcoming the crisis phenomena of the optimal environmental policy, based on the adoption of new ideological orientations in the interaction of society and nature, as well as on the implementation of a system of society on sustainable development in conditions of global transformation.
\end{abstract}

Key words: nature, society, consumer society, destruction, violence, mind, Enlightenment, negative dialectics, concept of sufficient development, noosphere worldview.

\section{Introduction.}

In the context of the aggravation of the global problems of our time, 
when mankind faced a threat to its immediate future, it is extremely important to make a choice of strategic development directions aimed at achieving the secure future. The current development vector based on consumer ideology turned out to be inadequate to the natural laws of evolution of the biosphere and led to unpredictable consequences. This is evidenced by the manifestations of the global ecological crisis, increasing environmental pollution, the exhaustion of natural resources, lack of living space, hunger problems and, most dangerous, the emergence of pandemic diseases that have swept at present almost all countries of the world community. Those colossal achievements that made it possible to achieve high living standards, increase average life expectancy, get rid of many diseases, achieve success in many areas of society, create modern technologies, increase means of communication and movement, and, in general, expand the horizons of the world, should not overshadow the indisputable fact that these achievements led to the degradation of nature, to a decrease in the quality of the environment and constitute a real threat to human existence.

The main part. Without exaggeration, we can say that at the beginning of the XXI century. the installation of a radical transformation of reality continues to be the dominant. Moreover, the confidence of political leaders in many countries in the correctness of their views and beliefs increases the risk of forcibly imposing their own vision of reality contrary to the requirements of natural laws. The paradox of this modern situation is that the flip side of this transformative activity is only the appearance of action and the leveling of responsibility.

It is for this reason that in modern conditions the primary task is to find new ways of socio-economic development aimed at overcoming the prevailing anthropocentric orientation towards nature based on its coordination with the laws of evolution of the biosphere. This will require the affirmation of new moral principles, new human qualities, a new humanism, the formation of which is possible on the basis of the «new» Enlightenment or noospheric worldview.

Representatives of the Frankfurt School of Neo-Marxism Theodor Adorno and Max Horkheimer, who were in they work «Dialectics of Enlightenment. Philosophical fragments» [5] had called into question the possibility of historical and scientific-technical progress and emphasized the problem of Enlightenment as a «shifter» of a certain attitude of consciousness, that is, when the focus on full cognition turns into super rationalization and insanity.

T. Adorno and M. Horkheimer had given the Enlightenment a negative meaning: they revealed the destructiveness of progress and criticized the priority of reason in solving social problems. Enlightenment was considered by them as a dialectical process: from creative power to the domination of man over nature and other individuals. The dialectic of the Enlightenment, 
from their point of view, is that the sublime and reasonable endeavors end with the bloody twentieth century. At the beginning of the XXI century, we can note as a radicalization of this process: from the bloody wars of the twentieth century to the modern global crisis of mankind, and the awareness of the need to overcome the «changeling» of the Enlightenment in its new projection of the noospheric worldview.

The ideas and conclusions about the destructive impact of science on nature, identified by representatives of the negative dialectics of the Enlightenment, have methodological potential for describing and explaining the reasons for the deepening global crises of our time, since they reflect the main social destruction and escalation of various forms of violence.These include the following.

1. The interaction of man on nature in the process of historical development turned out to be destructive, since the authoritative attitude of man towards the suppressed nature acted as a source of violence as a social destruction. Therefore, the separation of man from nature and its opposition was a turning point in history and determined the vector of development: civilization went along the destructive path of progress. The relationship of man to nature from direct turned into a violent attitude, the purpose of which is utilitarian benefit. As a result, the «path of the mind» has become the way of building power relations between man as the bearer of the mind and nature.
However, the dominance over nature turned against the thinking subject, leading to its reduction to insignificance [5].

2. The instinct of aggression and the almost complete absence of a mechanism restraining it in human nature as a biological species. T. Adorno and M. Horkheimer had shifted the focus from interclass conflict to the repressive attitude of man to nature, noting that human development was carried out through suppression and destruction. Realizing utilitarian utility, the mind becomes «technical», that is, it turns into a universal tool for exercising dominance over nature. A person also begins to be something instrumental, purely functional, and therefore easily replaceable. Therefore, recognizing power relations as all-determining, a man could not but become the object of power suppression.

3. A person ceases to perceive destruction as a negative phenomenon. The materialization of thinking takes place, and the Enlightenment becomes a hoax, regressing into mythology [5, p. 168]. The division into subject and object, into one who suppresses and what is suppressed, could not but lead to the alienation of the dominant subject from the object of submission. Nature loses its true diversity, is leveled as an object, thereby making it possible to affirm the universal repeatability within itself, obeying the principle of «everything is predetermined» $[4, \mathrm{p}$. 318].

T. Adorno and M. Horkheimer had defined the nature of the violence as ambivalent. On the one hand, in 
human nature the destructivenesswas «rooted», on the other hand, it can have a destructive and constructive nature, since man is endowed with creative power. It turns out that violence, destructiveness are integral components of self-preservation and development as a person and the society as a whole. Because of this, violence appears as a unique way man's relationship to the world, expressed in his schematization and simplification. As a result, the person is in clear, calculable world, but at the same time, the world loses its integrity, obessmyslivaet turns into an object of consumption and recycling. Man, being a part of the world, also becomes involved in this process of reification, and install it on overrationality, the desire to unify and to keep under control, turns around madness, the result of which is the formalization of relations, loss of sense of existence and celebration of violence.

Violence has become against nature turned the social destruction. Thus, the society became the «instance of violence» $[5$, p. 208], at the same time producing new forms of oppression and hiding it under the surface of normativity, the legitimacy of power. This self-concealment also appears as a consequence of destruction. The project of Enlightenment, according to the representatives of the Frankfurt school, there is a violent «imposition» of the mind, it is not surprising that the suppression begins to be seen as a necessary positive foundation of society. The veil that hides this tyrannical foundation supports social hierarchy and the «aestheticization of violence» $[5$, p. 209].

As for madness as utter rationalization, it is generated from a consumer attitude to the world, from a lack of creativity and desire for destruction. Madness is manifested in the loss of the integrity of the world, that is, only that which has utilitarian utility becomes valuable. Man seeks to simplify the world, thereby turning it into a kind of convenient scheme for use. The rationalization of human social life as consumption, acquiring the character of insanity, leads to an escalation of violence in society, as it further deepens the alienation of man from nature and his desire for selfdestruction.

Consequently, the destructiveness of violence is the consumer use of the mind for the sake of repression and domination. So, the ultimate rationality of the «Enlightenment project» turns into insanity, and the development of Western civilization is directly connected with the destructive attitude of a person both to nature and to himself [4].

One example of violence as selfdestruction can be represented by the idea of self-denial, the motif of the victim. Representatives of the Frankfurt school, through the analysis of the nature of sacrifice, substantiated the need for selfdestruction for the project of the Enlightenment. The rational way of relating to the world is identical with the sacrifice: as a priest, people and society in general seek to influence the nature, to obtain from it certain benefits in exchange for the victim. 
Thus, the sacrifice contains a rational component - profitable exchange.

Specific project of Enlightenment is the increased use of rational exchange scheme as a sacrifice, its projection on the relations of society, nature and man. The victim in this profitable exchange is at first nature, then man is himself, becoming in the process of industrialization and urbanization in a utilitarian thing, a tool. Accordingly, deformation of the relationship of industrial civilization and nature leads to a gap between nature and man, to their alienation, transforming the exchange into the hype, during which the person continues to be deceived himself.

«The non-equivalence of exchange is reflected in the fact that the relationship between man and nature are based on deception. No wonder T. Adorno and M. Horkheimer had chosen as an example the image of the trickster Odysseus, whose cheating rational resistance, which allows a person to escape the fate of being doomed. Odysseus, assessing their possible fate, eliminates the force that is directed against it, and through deceit rises to the level of consciousness using deception as a weapon of the mind» [4, p. 320].

In sum, Odysseus of technological civilization outwitted himself. That is why T. Adorno and M. Horkheimer had defined the history of modern civilization as «the history of introversion» [5, p. 75], i.e. the emergence of victims embarked on the path of self-denial, self-deception and dissolve in the mass. So, the representatives of the Frankfurt School anticipated and outlined many of the problems posed by the consumer society, and revealed the danger of over-rationalization in the technocratic world.

The negative consequences of the achievements of science and technology are evidence that it is a person who can reach mass suicide and at the same time destroy all other forms of life[2].

In view of this real danger, it is extremely important to take into account the main global risks that pose a threat to the normal functioning of people, to develop measures to eliminate them. In addition to the danger of a nuclear catastrophe, these risks include: everincreasing environmental pollution, leading to changes in climatic conditions, a lack of non-renewable and renewable natural resources, resource limitations associated with a lack of energy, food, water, and much more.

For a number of the third world countries, the particular danger is the lack of food, water, medicines, financial resources and other vital resources necessary for normal human life. Moreover, the lack of basic resources leads to conflicts and hostilities between different countries, and the ever-increasing demand for resources creates the danger of new conflicts of a global nature [3].

Currently, two types of risk are of particular importance- is the inequality between rich and poor, and inefficiency of the global governance process of global economic development. According to reports, currently 1 million people has the 
wealth owned by half the world's population.

The global economic crisis that began in 2008, has structural and systemic in nature and related to the fact that many countries in the world are not able to eliminate the existing risks. In the end, the global risk management of economically developed countries was at a low level.

The financial and economic crisis in almost all countries of the world community, led to a sharp increase in risk for global stability and the immediate future. And such danger as suggested by many experts, is quite real in the near future. Economic risks, as a consequence of macroeconomic imbalances, the negative phenomena in budgetary-tax sphere, weak financial markets, are expressing the totality of the facts leading to negative phenomena in the financial sector [2].

In addition, the aging of the population in developed countries creates a special tension in the financial sector and the increasing role of the shadow economy (organized crime, illegal trade, corruption, etc.) increases the risks of criminal procedure. High population growth is accompanied by growing violence in society and as a consequence to mass protests against the authorities and public order in general [1].

Moreover, these dangerous trends give the rise to rampant moneygrubbing, trust in power, aggressiveness of certain political figures who neglect humanistic values, and lead to the outbreak of military conflicts and an uncontrolled increase in military spending. These seemingly unusual human nature, selfdestructive qualities reflect the estrangement of man from himself and the estrangement from society as a whole. In this case, depending on whether humanity can cope with the dangers posed by science and technology, its near future depends.

In modern conditions, the internal crisis of man himself is particularly dangerous, his desire to ensure his well-being through the intensive use of natural resources and their irrational use, and therefore we have to admit that conflicts in the relationship between man and nature are generated by man himself, his desire to recklessly use its gifts and maximize break free from her addiction.

Conclusion. That is why, at present, there is an urgent need to search for new ways of socioeconomic development, aimed at reducing industrial pressure on the biosphere and aims to ensure the normal life of people. In the industrial sector required a new upgrade, focused on creating productions that fit into the structure of the biochemical cycles of the biosphere. This kind of value orientation shape the contours of adequate strategy of development, aimed at achieving the secure future. However, there is no doubt about the fact that overcoming environmental difficulties in the relationship between man and nature purely technical means is just one of the necessary conditions for achieving the sustainable future.

In the modern unsustainable development increasingly we have to 
spend effort and money on security. Here, the «protective» activity and the development of a divided and actually contradict each other as antagonists, as each for your expansion and realization takes away money from other areas. It is a unique manifestation of the law of conservation of energy in social activities. Therefore, the strategy for further sustainable evolution of global processes involves the coupling of action for the progressive development and security into a single system in which the effect is achieved mainly through the development and less - through protection. It implements a stronger interconnection of sustainable development and global security, its more uniform «distribution» in all directions of the planetary social and socio-natural activity [2].

Security issues in all its forms in the modern model of the existence and unstable development of mankind has come to the forefront and become the main activity, pushing the development issue to the periphery. However, in the future model of sustainable development, security will increasingly be ensured, mainly not through protection, but mainly through development. Moreover, it will be a self-sustaining balanced, that is, sustainable development, which will not generate and significantly increase the dangers, threats, negative consequences, etc.

Therefore, it is important to significantly expand the subject field of the study of the problem of global sustainability, to improve the concept of sustainable development, to make it multi-vector, system-holistic and thereby adequate, capable of more efficient implementation with the help of emerging global technologies of socio-economic and humanitariannoospheric orientation.

Thus, the development of an optimal environmental policy based on the approval of new ideological orientations in the interaction of society and nature, as well as on the implementation of the society's attitude towards sufficient development in the context of global transformation, is of particular importance in overcoming crisis phenomena.

The security of society and the state in a globalizing world depends on the formation of a modern, socalled «noospheric» worldview («new» Enlightenment), a system of new humanistic knowledge and values, thanks to which that make it possible to formulate productive answers to the challenges and risks of globalization, anthropological and environmental crises, transformation and escalation of violence.

We are talking about the formation of the new environmentally oriented thinking based on the principles of joint, balanced co-development of man, society and nature and the choice of a sufficient development strategy as a new way of socioeconomic development, taking into account the need to preserve the environment and change human qualities. 


\section{СПИСОК ИСПОЛЬЗОВАННЫХ ИСТОЧНИКОВ}

1. Бодрийяр, Жан. Общество потребления. Его мифы и структуры. Перевод на русский язык: Е. А. Самарская. М., 2006. Электронная публикация: Центр гуманитарных технологий. -

26.10.2008. URL: https://gtmarket.ru/laboratory/basis/3464

2. Водопьянов, П. А., Крисаченко, В. С. Стратегия бытия человечества: от апокалиптики к ноосферному. Минск: Беларуская навука, 2018.

3. Дуднікова, I. I. Напрями вирішення проблем антропогенного впливу на природу, людину, суспільство та досягнення сталого розвитку. Гуманітарний вісник Запорізької державної інженерної академії: збірник наукових пращь. Запоріжжя : ЗНУ, 2019. 77. 2334.

4. Сидоренко, И. Н. Франкфуртская школа о социальном насилии как деструкции. Научные труды Республиканского института Высшей школь. Философскогуманитарные науки: сб. науч. ст. Минск, 2017. 16. 316-323.

5. Хоркхаймер, М., Адорно, Т. Диалектика Просвещения: философские фрагменты. М.; СПб.: Медиум Ювента, 1997. 312.

\section{REFERENCES}

1. Baudrillard, Jean, 2006. Consumer society. His myths and structures. Translation into Russian: E. A. Samarskaya. M.: Electronic publication: Center for humanitarian technologies.

10/26/2008. URL: https://gtmarket.ru/laboratory/basis/3464

2. Vodopyanov, P. A. \& Krisachenko V. S., 2018. The strategy of humanity: from apocalyptic to noospheric. Minsk. Belarusian Navuka.

3. Dudnikova, I. I., 2019. Directly, the problems of anthropogenic influx into nature, ludin, suspension and access to steel roving. Humanitarian newsletter of the Zaporizhzhya State Engineering Academy / Goal. ed. V.H. Voronkova. Zaporizhzhia: «View of ZNU». 77. 23-34.

4. Sidorenko, I. N., 2017. Frankfurt School of Social Violence as Destruction. Scientific works of the Republican Institute of Higher Education. Philosophical and humanitarian sciences: Sat. scientific Art. Minsk. 16. 316-323.

5. Horkheimer, M. \& Adorno T., 1997. Dialectics of Enlightenment: philosophical fragments. M.; St. Petersburg: Medium of Juventa. 312.

ВОДОП'ЯНОВ, П. О. - доктор філософських наук, професор, професор кафедри філософії i права, Білоруський державний технологічний університет, членкореспонедент Національної академії Білорусі (Республіка Білорусь, Мінськ)

E-mail: pva1940@bk.ru, ORCID iD: http://orcid.org/ 0000-0002-7881-4114

Belarusian State Technical University 13a, Sverdlova str., Minsk, 220006,Republic of Belarus

СИДОРЕНКО, І. М. - доктор філософських наук, доцент, доцент кафедри філософії і методології науки, Білоруський державний університет (Републіка Білорусь, Мінськ)

E-mail: iri_na2000@rambler.ru, ORCID iD: http://orcid.org/0000-0001-7792-0102 Belarusian State University 9, Kal'variyskaya str., Minsk, 220050,Republic of Belarus

\section{НА ШЛЯХУ ДО «НОВОГО ПРОСВІТНИЦТВА» ЯК АЛЬТЕРНАТИВА СУСПІЛЬСТВУ СПОЖИВАННЯ}


Мета статті - виявити основні ризики і загрози суспільства споживання, яке переворило розум в утилітарний засіб для насилля над природою, і на основі цього розкрити доцільність переходу до «нового» Посвітництва, що передбачає реалізацію стратегії достатнього розвитку і формування ноосферного світогляду.

Методологія дослідження: використана комплексна методологія, a саме: історичний i логічний метод, метод компаративного аналізу, метод історикофілософської реконструкції, системний метод. У якості методологічної бази виступили концепції негативної діалектики і соціальної деструкції Т.Адорно і М.Горкхаймера; концепція суспільства споживання Ж.Бородрійяра; а також авторські розробки стратегії стійкого розвитку і стратегії довгострокового розвитку (П.О. Водоп'янов, В.С Крисаченко), філософії насилля (І.М. Сидоренко).

Наукова новизна дослідження в обгрунтуванні концепції достатнього розвитку на основі «нового» Просвітництва i формування ноосферного світогляду, а також виявлення методологічного потенціалу концепції негативної діалектики і соціальної деструкції для розуміння причин глобальних криз сучасності, зокрема, екологічної. Висновки. В якості основних висновків, автори статті розвивають, по-перше, ідею про те, що подолання екологічних утруднень у взаємовідносинах людини і природи суто технічними засобами $є$ лише однією 3 необхідних умов досягнення стабільного майбутнього; по-друге, розкривають сутність «нового» Просвітництва як гармонізації розвитку і захисту, що знаходить своє здійснення у концепції достатнього розвитку, що знаходить своє здійсненя у концепції достатнього розвитку і передбачає поєднання дій 3 поступово-прогресивного розвитку і забезпечення безпеки в єдину систему; по-третє, ідею про особливе значення у подоланні кризових явищ оптимальної екологічної політики, що базується на утвердженні нових світоглядних орієнтацій у взаємодії суспільства і природи, а також на реалізації установки соціуму на достатній розвиток в умовах глобальної трансформації.

Ключові слова: природа, соціум, суспільство споживання, деструкція, насилля, розум, Просвітництво, негативна діалектика, стратегія достатнього розвитку, ноосферний світогляд.

ВОДОПьЯНОВ, П. А. - доктор философских наук, профессор, профессор кафедры философии и права, Белорусского государственного технологического университета, член-корреспондент Национальной академии наук Беларуси (Республика Беларусь, Минск)

E-mail: pva1940@bk.ru, ORCID iD: 0000-0002-7881-4114

СИДОРЕНКО, И. Н. - доктор философских наук, доцент, доцент кафедры философии и методологии науки Белорусского государственного университета (Республика Беларусь, Минск)

E-mail: iri_na2000@rambler.ru, ORCID iD : 0000-0001-7792-0102

\section{НА ПУТИ К «НОВОМУ ПРОСВЕЩЕНИЮ» КАК АЛЬТЕРНАТИВА ОБЩЕСТВУ ПОТРЕБЛЕНИЯ}

Цель статьи - выявить основные риски и опасности общества потребления, превратившего разум в утилитарное средство для насилия над природой, и на основании этого раскрыть целесообразность перехода к «новому» Просвещению, предполагающего реализацию стратегии достаточного развития и формирования ноосферного мировоззрения.

Методология исследования: использована комплексная методология, а именно: исторический и логический метод, метод компаративного анализа, метод историкофилософской реконструкции, системный метод. В качестве методологической базы выступили концепции негативной диалектики и социальной деструкции Т. Адорно и

On the way to «New Enlightenment» as an alternative to consumer society 
М.Хоркхаймера; концепция общества потребления Ж. Бодрийяра; а также авторские разработки стратегии устойчивого развития и стратегии достаточного развития (П.А. Водопьянов, Крисаченко В.С.), философии насилия (И.Н. Сидоренко).

Научная новизна исследования заключается в обосновании концепции достаточного развития на основе «нового» Просвещения и формирования ноосферного мировоззрения, а также выявлении методологического потенциала концепции негативной диалектики и социальной деструкции для понимания причин глобальных кризисов современности, в частности, экологического. Выводы. В качестве основных выводов, авторы статьи развивают, во-первых, идею о том, что преодоление экологических затруднений во взаимоотношениях человека и природы сугубо техническими средствами является лишь одним из необходимых условий достижения стабильного будущего; во-вторых, раскрывают сущность «нового» Просвещения как гармонизации развития и защиты, что находит свое осуществление в концепции достаточного развития и предполагает соединение действий по поступательнопрогрессивному развитию и обеспечению безопасности в единую систему; в-третьих, идею об особом значении в преодолении кризисных явлений оптимальной экологической политики, основывающейся на утверждении новых мировоззренческих ориентаций во взаимодействии общества и природы, а также на реализации установки социума на достаточное развитие в условиях глобальной трансформации.

Ключевые слова: природа, социум, общество потребления, деструкция, насилие, разум, Просвещение, негативная диалектика, стратегия достаточного развития, ноосферное мировоззрение.

Received date 15.01.2020

Accepted date 01.02.2020

Published date 10.02.2020 